\title{
Mechanism of the Combined Effects of Bacillus subtilis FHC 402-Derived Antibacterial Factor and Hexametaphosphate on Escherichia coli
}

\author{
Takahisa Mryamoto, Koji Ohyama, Makoto Yoshimoto \\ and Shoji HaTANO \\ Department of Food Science and Technology, Faculty of Agriculture, \\ Kyushu University 46-09, 6-10-1, Hakozaki, Higashi-ku, \\ Fukuoka 812, Japan \\ Received September 7, 1987
}

\begin{abstract}
The combined use of Bacillus subtilis FHC 402-derived antibacterial factor (BAF) and hexametaphosphate (HP) inhibited the growth of E. coli. To elucidate the mechanism of the inhibition, the effects of BAF and/or HP on respiration, liberation of cellular components, and macromolecular synthesis were studied. HP liberated protein, LPS, and $\mathrm{Mg}^{2+}$ from the cells, suggesting damage to the membrane. Further, HP decreased oxygen uptake and the incorporation of $\left[{ }^{14} \mathrm{C}\right]$ leucine, $\left[{ }^{3} \mathrm{H}\right]$ uridine, and $\left[{ }^{3} \mathrm{H}\right]$ thymidine into the cells. In contrast, BAF did not damage the outer membrane nor enhance the effects of HP on the membrane. HP or BAF had little or no effect on the incorporation of labeled compounds into the TCA-insoluble fraction. The combined use of $\mathrm{BAF}$ and $\mathrm{HP}$ decreased the incorporation of $\left[{ }^{14} \mathrm{C}\right]$ leucine into the fraction much more than that of $\left[{ }^{3} \mathrm{H}\right]$ uridine and $\left[{ }^{3} \mathrm{H}\right]$ thymidine, suggesting that the combined use essentially inhibits protein synthesis but not RNA and DNA synthesis. BAF also inhibited protein synthesis in the cell-free system. The antibacterial action of the combined use of BAF and HP in E. coli seems likely to be that the damage to the outer membrane caused by HP enables BAF to penetrate the membrane and inhibit protein synthesis.
\end{abstract}

Gram-negative bacteria are relatively resistant to antibacterial substances owing to their outer membrane. ${ }^{1)}$ To overcome this resistance, synergistic antibacterial activity against gram-negative bacteria has been examined using various antibacterial substances in combination. $^{2 \sim 4)}$ Tsutsumi et al. ${ }^{5,6)}$ have reported that the growth of gram-negative bacteria is greatly inhibited by the combined use of polyphosphates and such detergents as sodium cholate or glycerol monocaprate.

Our previous studies have shown that the culture supernatant from Bacillus subtilis FHC 402 contains a novel antibacterial factor (abbreviated BAF). ${ }^{7)}$ BAF is a glycopeptide consisting of 22 molecules of 8 different amino acids, 3 hexoses, 1 hexosamine, 1 deoxyribose, and unknown substances. ${ }^{78}$ The single use of BAF greatly inhibits the growth of Salmonella typhimurium but only slightly that of Esche- richia coli. ${ }^{9)}$ The growth of $E$. coli, however, is strongly inhibited by the combined use of BAF and hexametaphosphate (HP), a food additive. ${ }^{9)}$ The primary site of the antibacterial action of BAF is demonstrated to be in the process of protein synthesis in $S$. typhimurium, ${ }^{10)}$ but the mechanism of the combined effects of BAF and HP on E. coli remains to be resolved.

For this work, the effects of BAF and/or HP on oxygen uptake, liberation of cellular components and macromolecular synthesis in $E$. coli were investigated.

\section{MATERIALS AND METHODS}

Strains. Escherichia coli IFO 3301 and Salmonella typhimurium IFO 12529 were obtained from the Institute for Fermentation, Osaka.

Chemicals. $\left[{ }^{14} \mathrm{C}\right]$ Leucine $(342 \mathrm{mCi} / \mathrm{mmol}),\left[{ }^{3} \mathrm{H}\right]$ uridine 
$(24.3 \mathrm{Ci} / \mathrm{mmol})$, and $\left[{ }^{3} \mathrm{H}\right]$ thymidine $(18.2 \mathrm{Ci} / \mathrm{mmol})$ were obtained from New England Nuclear Co. Pyruvate kinase was purchased from Toyobo Co., Ltd. ATP, GTP, and NADH were products of Oriental Yeast Co., Ltd. All other reagents used were of analytical grade.

Preparation of $B A F$. BAF was prepared from the culture supernatant of Bacillus subtilis FHC 402 by the methods described previously. ${ }^{8)}$ The antibacterial potency of BAF was assayed by the paper-disc plate method using E. coli as a test organism. ${ }^{8}$

Assay of combined effects on the growth of $E$. coli. The combined effects of BAF and 5 polyphosphates or EDTA on the growth of $E$. coli were assayed by the tube-dilution method described previously. ${ }^{9}$ )

Treatment of E. coli with BAF and/or HP. E. coli was treated with BAF and/or HP as described previously. ${ }^{9}$ )

Measurement of cellular components liberated from $E$. coli by treatment with $B A F$ and/or $H P$. Immediately after the treatment with $\mathrm{BAF}$ and/or $\mathrm{HP}$, the mixture was centrifuged for $15 \mathrm{~min}$ at $9000 \times g$ at $4^{\circ} \mathrm{C}$. The resulting supernatant was used for the measurement of the cellular components. Proteins were precipitated with hot $5 \%$ TCA, dissolved in $0.1 \mathrm{~N} \mathrm{NaOH}$, and their concentrations estimated by the method of Lowry et al. ${ }^{11)}$ Lipopolysaccharides (LPS) were measured by the method of Osborn. ${ }^{12,13)} \mathrm{Mg}^{2+}$ was analyzed with a Beckman NFIB atomic absorption spectrophotometer.

Measurement of oxygen uptake. After the treatment with BAF and/or HP, the cells were collected by centrifugation for $5 \mathrm{~min}$ at $4000 \times g$ at $4 \mathrm{C}$ and washed twice with $50 \mathrm{~mm}$ potassium phosphate buffer $(\mathrm{pH} 7.3)$. The residual cells were suspended, and the turbidity $\left(A_{660}\right)$ of the cell suspension was adjusted to 1.0 with the same buffer. Oxygen uptake was measured with a Clarktype oxygen electrode. ${ }^{10,14)}$ After measuring the oxidation of the endogenous substrates, a substrate solution was added to the mixture at a final concentration of $10 \mathrm{~mm}$ to measure the substrate oxidation. The increment of the rate of oxygen uptake accompanied by the substrate oxidation was expressed as ng oxygen per min per $\mathrm{mg}$ protein of cells. After the alkali treatment of the cells, proteins were measured by the method of Lowry et al. ${ }^{11)}$

Incorporation of labeled compounds into whole cells and the TCA-insoluble fraction. ${ }^{15,16)}\left[{ }^{14} \mathrm{C}\right] \mathrm{Leucine}(1 \mu \mathrm{Ci}$, $0.03 \mu \mathrm{mol}), \quad\left[{ }^{3} \mathrm{H}\right]$ uridine $(2 \mu \mathrm{Ci}, \quad 8.23 \mu \mathrm{mol})$, or $\left[{ }^{3} \mathrm{H}\right]-$ thymidine $(2 \mu \mathrm{Ci}, 0.11 \mu \mathrm{mol})$ was added to $5 \mathrm{ml}$ of the exponential culture of $E$. coli and incubated at $30^{\circ} \mathrm{C}$ for a suitable interval. When the effects of BAF and/or HP on the incorporation of these labeled compounds were examined, BAF solution $(12,000$ units $/ \mathrm{ml})$ and/or $20 \% \mathrm{HP}$ solution were added to the mixture in a final concentration of 200 units $/ \mathrm{ml}$ and $1 \%$, respectively. The radioactivity incorporated into whole cells and the TCA-insoluble fraction was counted by a liquid scintillation spectrometer. ${ }^{10)}$

Protein synthesis in a cell-free system. The ribosome S-30 fraction was prepared from the exponentially growing cells of $E$. coli and S. typhimurium by the method of Matthaei and Nirenberg. ${ }^{17)}$ The experimental conditions were the same as those described in our previous paper $^{10)}$ except that the reaction mixture contained $1.8 \mathrm{mg}$ protein of the S-30 fraction from $E$. coli or $S$. typhimurium. When the effects of BAF on protein synthesis were examined, the reaction mixture contained 200 or 800 units $/ \mathrm{ml} \mathrm{BAF}$. The radioactivity incorporated into the hot TCA-insoluble fraction was counted.

\section{RESULTS}

The combined effects of BAF and polyphosphates on the growth of E. coli

As Table I shows, none of the polyphosphates used had significant effects on the growth of $E$. coli at a concentration of $1 \%$ in the absence of BAF. HP and ultraphosphate, however, completely inhibited the growth in the presence of 100 units $/ \mathrm{ml}$ of BAF. In the presence of 200 units/ml of BAF, tetrapolyphosphate essentially inhibited the growth. Pyrophosphate and tripolyphosphate also had combined effects with BAF.

\section{The combined effects of BAF and EDTA on the growth of $E$. coli}

EDTA, a chelating agent, damages the outer membrane of gram-negative bacteria. $\left.{ }^{18}\right) \mathrm{HP}$ also has a chelating effect. ${ }^{19)}$ To compare

TABle 1. EFFects of BAF on Growth of E. coli in the Presence of Polyphosphate

\begin{tabular}{lllll}
\hline & \multicolumn{4}{c}{ Growth $\left(A_{660}\right)$} \\
\cline { 2 - 5 } \begin{tabular}{l} 
Polyphosphate \\
\cline { 2 - 5 }
\end{tabular} & \multicolumn{4}{c}{ BAF (units/ml) } \\
& 0 & 100 & 200 & 400 \\
\hline Control & 0.53 & 0.50 & 0.50 & 0.48 \\
Pyrophosphate & 0.48 & 0.42 & 0.35 & 0.06 \\
Tripolyphosphate & 0.51 & 0.44 & 0.21 & 0.07 \\
Tetrapolyphosphate & 0.52 & 0.47 & 0.06 & 0.03 \\
Hexametaphosphate & 0.48 & 0 & 0 & 0 \\
Uitraphosphate & 0.51 & 0 & 0 & 0 \\
\hline
\end{tabular}


EDTA with HP in action, the combined effects of BAF and EDTA on $E$. coli were investigated. E. coli decreased the growth rate with an increase in EDTA concentration, though the growth was not completely inhibited by EDTA even at $4 \mathrm{~mm}$. The growth, however, was completely suppressed by $4 \mathrm{~mm}$ EDTA and 400 units $/ \mathrm{ml} \mathrm{BAF}$ in combination.

TABle II. Liberation of Cellular Components FROM $E$. coli BY TREATMENT WITH BAF AND/OR HP

\begin{tabular}{lccc}
\hline Treatment & $\begin{array}{c}\text { Protein } \\
\mathrm{mg} / \mathrm{g}(\%)\end{array}$ & $\begin{array}{c}\text { LPS } \\
\mathrm{mg} / \mathrm{g}(\%)\end{array}$ & $\begin{array}{c}\mathrm{Mg}^{2+} \\
\mathrm{mg} / \mathrm{g}(\%)\end{array}$ \\
\hline Intact cells & $629.0^{*}(100)$ & $60.3 *(100)$ & $4.1^{*}(100)$ \\
Control & $0.2(0.03)$ & $0.1(0.2)$ & $0.1(2.9)$ \\
200 units/ml & $0.3(0.05)$ & $0.3(0.5)$ & $0.2(3.6)$ \\
BAF & & & $1.2(28.5)$ \\
$1 \%$ HP & $23.5(3.7)$ & $13.5(22.4)$ & $1.2(24.6)$ \\
BAF and HP & $34.0(5.4)$ & $12.5(20.7)$ & $1.0(2.0)$ \\
\hline
\end{tabular}

* Values are expressed as mg per g-dry weight of cells.
Liberation of cellular components from $E$. coli by treatment with $B A F$ and/or $H P$

To clarify the role of BAF and HP in the combined effects, the liberation of protein, LPS, and $\mathrm{Mg}^{2+}$ from E. coli was measured after the treatment with $\mathrm{BAF}$ and/or HP. Table II shows that 200 units $/ \mathrm{ml}$ of BAF had

Table III. Oxygen Uptake of $E$. coli Treated WITH BAF AND/OR HP

\begin{tabular}{|c|c|c|c|c|}
\hline \multirow{3}{*}{$\begin{array}{l}\text { Substrate } \\
(10 \mathrm{~mm})\end{array}$} & \multicolumn{4}{|c|}{ Increment of oxygen uptake } \\
\hline & \multicolumn{4}{|c|}{ Treatment } \\
\hline & Control & $\begin{array}{c}\text { BAF } \\
(200 \\
\text { units } / \mathrm{ml})\end{array}$ & $\begin{array}{c}\mathrm{HP} \\
(1 \%)\end{array}$ & $\begin{array}{l}\mathrm{BAF} \\
(200 \\
\text { units } / \mathrm{ml})\end{array}+\underset{(1 \%}{\mathrm{HP}}$ \\
\hline Glucose & $77^{*}$ & $82 *$ & $5^{*}$ & $5^{*}$ \\
\hline Succinate & 84 & 77 & 55 & 49 \\
\hline Lactate & 277 & 252 & 199 & 199 \\
\hline NADH & 13 & 11 & 4 & 4 \\
\hline
\end{tabular}

* Values are expressed as ng oxygen per min per mg protein of cells.

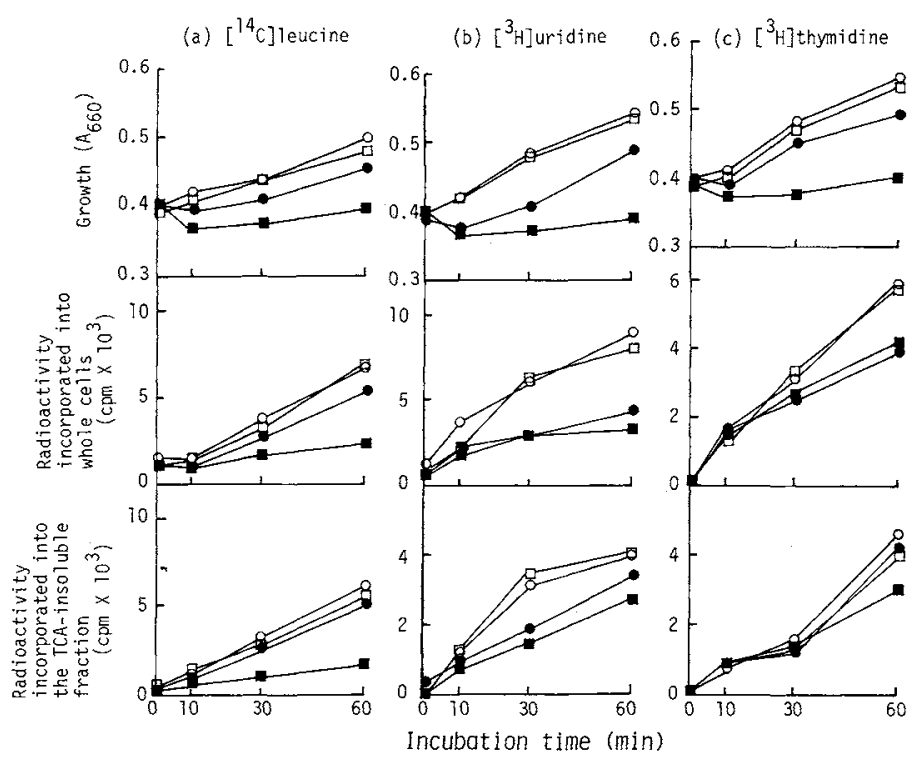

FIG. 1. Effects of BAF and/or HP on the Incorporation of $\left[{ }^{14} \mathrm{C}\right]$ Leucine, $\left[{ }^{3} \mathrm{H}\right]$ Uridine, and $\left[{ }^{3} \mathrm{H}\right] \mathrm{Thymidine}$ into Whole Cells and the TCA-Insoluble Fraction in E. coli.

BAF and/or HP solutions were added to a $5-\mathrm{ml}$ culture of $E$. coli in the exponential phase of growth. Immediately after addition of the substance(s), $\left[{ }^{14} \mathrm{C}\right]$ leucine $(1 \mu \mathrm{Ci}, 0.03 \mu \mathrm{mol}),\left[{ }^{3} \mathrm{H}\right]$ uridine $(2 \mu \mathrm{Ci}, 8.23 \mu \mathrm{mol})$, or $\left.{ }^{3} \mathrm{H}\right]$ thymidine $(2 \mu \mathrm{Ci}, 0.11 \mu \mathrm{mol})$ was added to the culture. The mixture was incubated at $30^{\circ} \mathrm{C}$ for a suitable interval. In the case of $\left[{ }^{3} \mathrm{H}\right]$ thymidine, the reaction mixture was supplemented with $2 \mathrm{mg}$ of deoxyadenosine. The radioactivity incorporated into whole cells and the TCA-insoluble fraction was measured. Symbols: $\bigcirc$, control; $\square, 200$ units/ml BAF; 
no effect on the liberation of these components from the cells. However, the treatment with $1 \%$ HP liberated about $4 \%, 22 \%$, and $29 \%$ of total cell protein, LPS; and $\mathrm{Mg}^{2+}$, respectively. BAF hardly facilitated the liberation caused by HP.

\section{Oxygen uptake of E. coli treated with BAF and/or $H P$}

The effects of BAF and/or HP on oxygen uptake were tested in E. coli. The HP-treated cells greatly decreased the respiration to about $5 \%$ of the control but BAF had no significant effect when glucose was added (Table III). The addition of succinate, lactate, or NADH also considerably diminished the oxygen uptake (Table III). The oxygen consumption of the BAF-and-HP-treated cells was similar to that of the HP-treated cells (Table III).

\section{Effects of BAF and/or HP on incorporation of labeled compounds into whole cells and the TCA-insoluble fraction in $E$. coli}

Figure 1 shows that, although the combined use of BAF and HP strongly inhibited the growth of $E$. coli, BAF ( 200 units $/ \mathrm{ml}$ ) had no significant effect. The incorporation of $\left[{ }^{14} \mathrm{C}\right]-$ leucine, $\left[{ }^{3} \mathrm{H}\right]$ uridine, and $\left[{ }^{3} \mathrm{H}\right]$ thymidine into whole cells and the TCA-insoluble fraction was also unaffected by BAF. The $\left[{ }^{14} \mathrm{C}\right]-$ leucine incorporation into whole cells and the TCA-insoluble fraction was slightly inhibited by $1 \% \mathrm{HP}$ after a $60-\mathrm{min}$ incubation, while the combined use of BAF and HP greatly decreased these incorporations to about $25 \%$ of the control (Fig. la). The incorporation of $\left[{ }^{3} \mathrm{H}\right]$ uridine into whole cells was decreased to about $40 \%$ of the control by HP alone and by the combined use after a $60-\mathrm{min}$ incubation (Fig. 1b). HP decreased the incorporation into the cold TCA-insoluble fraction by about $20 \%$ after a 60 -min incubation, the inhibition rate being slightly increased by the combined use (Fig. 1b). HP also decreased the $\left[{ }^{3} \mathrm{H}\right]$ thymidine incorporation into whole cells by about $30 \%$ after a 60 -min incubation, and the inhibition rate was not changed by

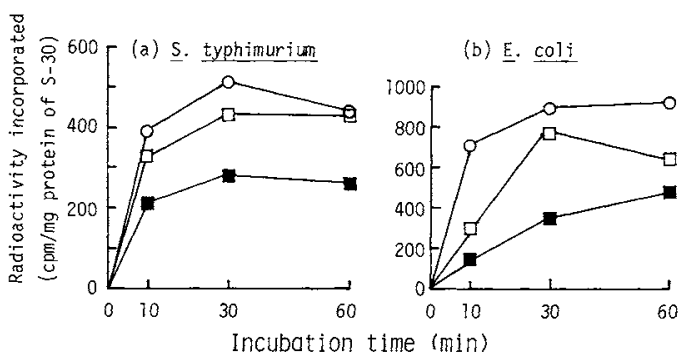

FIG. 2. Effects of BAF on Protein Synthesis in Cell-free System from $E$. coli and $S$. typhimurium.

The reaction mixture for protein synthesis contained the following components in a final volume of $200 \mu \mathrm{l}: 50 \mathrm{~mm}$ Tris-hydrochloric acid buffer $(\mathrm{pH} \mathrm{7.8)}, 1.8 \mathrm{mg}$ protein of the S-30 fraction from $E$. coli or $S$. typhimurium, $60 \mathrm{mM}$ ammonium chloride, $9 \mathrm{~mm}$ magnesium acetate, $1 \mathrm{~mm}$ dithiothreitol, $1 \mathrm{~mm}$ ATP, $0.2 \mathrm{~mm}$ GTP, $5 \mathrm{~mm}$ phosphoenol pyruvate, $30 \mu \mathrm{g} / \mathrm{ml}$ pyruvate kinase, $0.05 \mathrm{~mm}$ each of 19 amino acids (except leucine), $0.02 \mathrm{~mm}\left[{ }^{14} \mathrm{C}\right]$ leucine $(0.2 \mu \mathrm{Ci})$, and $\mathrm{BAF}$ at 200 or 800 units $/ \mathrm{ml}$. The reagents were mixed at $0^{\circ} \mathrm{C}$, and the reaction was initiated by raising the temperature of the mixture to $35^{\circ} \mathrm{C}$. The radioactivity incorporated into the hot TCA-insoluble fraction was measured. Symbols: $O$, control; $\square$, 200 units/ml BAF; $\mathbf{\square}, 800$ units/ml BAF.

the presence of BAF (Fig. 1c). The incorporation of $\left[{ }^{3} \mathrm{H}\right]$ thymidine into the TCA-insoluble fraction was scarcely inhibited by HP and was decreased by about $30 \%$ by the combined use after a 60 -min incubation (Fig. 1c).

Effects of BAF on protein synthesis in cell-free systems from $E$. coli and $S$. typhimurium

The cell-free protein synthesis from $E$. coli was compared with that from $S$. typhimurium in sensitivity toward BAF. BAF somewhat inhibited the incorporation at $200 \mathrm{units} / \mathrm{ml}$ in both the systems and greatly to about 50 and $40 \%$ of the control, at 800 units $/ \mathrm{ml}$ after a 30 min incubation in the systems from $S$. typhimurium and $E$. coli, respectively (Fig. $2 \mathrm{a}$ and b). These results indicate that BAF affects the in vitro protein synthesis in $E$. coli as well as $S$. typhimurium.

\section{DISCUSSION}

Polyphosphate has a chelating effect, and the effect increases with increasing chain 
length. ${ }^{19)}$ The combined effects of BAF and polyphosphate on the growth of $E$. coli increased with an increase in the chain length of polyphosphate (Table I). BAF also inhibited growth in the presence of EDTA, a chelating agent. Leive ${ }^{18,20)}$ has reported that the treatment of $E$. coli with EDTA results in the liberation of approximately half of LPS from the outer membrane of the cells. It has also been reported that LPS is respensible for the resistance of gram-negative bacteria to various antibacterial substances, ${ }^{21)}$ and $\mathrm{Mg}^{2+}$ is important for maintaining the structure of LPS $^{22)}$ As Table 2 shows, the treatment of $E$. coli with HP alone resulted in the liberation of protein, LPS, and $\mathrm{Mg}^{2+}$ from the cells. These results and the facts suggest that the chelating effect of HP is important in the combined effects of BAF and HP on $E$. coli and that LPS in the outer membrane functions as a barrier against the antibacterial action of BAF.

HP decreased oxygen uptake and the incorporation of $\left[{ }^{14} \mathrm{C}\right]$ leucine, $\left[{ }^{3} \mathrm{H}\right]$ uridine, and $\left[{ }^{3} \mathrm{H}\right]$ thymidine into whole cells (Table III and Fig. 1). Suda ${ }^{23)}$ has reported that HP affects the function of porin protein, which constitutes a hydrophilic pathway in the outer membrane. HP seems likely to inhibit the penetration of hydrophilic compounds through the outer membrane. In contrast to HP, BAF had no effect on the liberation of cellular components, the oxygen uptake, or the incorporation of the labeled compounds into whole cells (Tables II, III and Fig. 1). In addition, BAF did not facilitate the changes in the outer membrane caused by HP as described above (Tables II, III and Fig. 1). These results suggest that BAF has no effect on the structure and function of the outer membrane. $\mathrm{We}^{9)}$ have reported that $\mathrm{HP}$ does not affect the growth of the BAF-treated $E$. coli, though BAF prolongs the lag phase of the growth of the HP-treated cells. The damage to the outer membrane caused by HP is probably required for the antibacterial action of BAF.

The combined use of $\mathrm{BAF}$ and $\mathrm{HP}$ inhibited the incorporation of $\left[{ }^{14} \mathrm{C}\right]$ leucine into the TCA-insoluble fraction much more than that of $\left[{ }^{3} \mathrm{H}\right]$ uridine and $\left[{ }^{3} \mathrm{H}\right]$ thymidine (Fig. 1). The result suggests that the combined use essentially inhibits protein synthesis in $E$. coli but not RNA and DNA synthesis. Since BAF has been demonstrated to inhibit protein synthesis in the cell-free system from S. typhimurium, ${ }^{10}{ }^{1}$ the effect of BAF on protein synthesis in the cell-free system from $E$. coli was compared with that in the system from $S$. typhimurium. BAF markedly inhibited the cell-free protein synthesis from $E$. coli to a similar extent to that from $S$. typhimurium (Fig. 2). These results suggest that the primary site of antibacterial action of BAF is in protein synthesis in $E$. coli as well as $S$. typhimurium.

In conclusion, the antibacterial action of the combined use of BAF and HP in E. coli seems likely to be that the damage to the outer membrane caused by HP, especially the liberation of LPS from the membrane, enables BAF to penetrate the membrane and inhibit protein synthesis.

\section{REFERENCES}

1) S. Mizushima and K. Nakamura, Protein, Nucleic Acid and Enzyme, 22, 21 (1977).

2) J. M. T. Hamilton-Miller, J. T. Smith and R. Knox, Nature, 201, 867 (1964).

3) L. D. Sabath and E. P. Abraham, Nature, 204, 1066 (1964).

4) R. Sutherland and F. R. Batchelor, Nature, 201, 868 (1964).

5) M. Tsutsumi, K. Nishimura, K. Yasui, A. Matsuoka and T. Watanabe, J. Food Hyg. Soc. Japan, 17, 273 (1976).

6) M. Tsutsumi, K. Yasui, K. Isshiki and T. Watanabe, J. Food Hyg. Soc. Japan, 18, 341 (1977).

7) M. Tsutsumi, T. Miyamoto, I. Suda and T. Watanabe, J. Fac. Agric., Kyushu Univ., 26, 71 (1982).

8) T. Miyamoto, M. Yoshimoto, M. Tsutsumi, K. Yamada and S. Hatano, Agric. Biol. Chem., 50, 1169 (1986).

9) T. Miyamoto, K. Yamada and S. Hatano, J. Food Hyg. Soc. Japan, 28, 364 (1987).

10) T. Miyamoto, K. Kunitake and S. Hatano, Agric. Biol. Chem., 52, 649 (1988).

11) O. H. Lowry, N. J. Rosebrough, A. L. Farr and R. J. Randall, J. Biol. Chem., 193, 265 (1951).

12) M. J. Osborn, Proc. Natl. Acad. Sci. U.S.A., 50, 499 (1963).

13) K. G. Johnson and M. B. Perry, Can. J. Microbiol., 
22, 29 (1976)

14) "Biological Structure and Function," Vol. 2, ed. by T. W. Goodwin and O. Lindberg, Academic Press Inc., 1961, pp. $71 \sim 83$.

15) Y. Sokawa and J. Sokawa, "Seikagaku-JikkenKouza," Vol. 7, ed. by Biochemical Society of Japan, Tokyo-Kagaku-Dojin Co., 1975, pp. $563 \sim 590$.

16) K. Tanaka, S. Watanabe and M. Tamaki, $J$. Antibiot., 23, 13 (1970).

17) J. H. Matthaei and M. W. Nirenberg, Proc. Natl. Acad. Sci. U.S.A., 47, 1580 (1961).
18) L. Leive, Biochem. Biophys. Res. Commun., 21, 290 (1965).

19) J. R. Wazer and D. A. Campanella, J. Am. Chem. Soc., 72, 655 (1950).

20) L. Leive, Biochem. Biophys. Res. Commun., 18, 13 (1965).

21) H. Nikaido, Angew. Chem. Int. Ed. Engl., 18, 337 (1979).

22) K. Nakamura and S. Mizushima, Biochim. Biophys. Acta, 413, 371 (1975).

23) I. Suda, Doctoral thesis, Kyushu Univ., 1981, pp. $181 \sim 185$. 